Natural Hazards and Earth System Sciences (2004) 4: 475-483

SRef-ID: 1684-9981/nhess/2004-4-475

(C) European Geosciences Union 2004

\title{
Magnitude and frequency of landslides triggered by a storm event, Loughborough Inlet, British Columbia
}

\author{
R. H. Guthrie ${ }^{1}$ and S. G. Evans ${ }^{2}$ \\ ${ }^{1}$ Ministry of Water, Land and Air Protection, Vancouver Island Region, 2080A Labieux Road, Nanaimo, British Columbia \\ V9T 6J9, Canada \\ ${ }^{2}$ Department of Earth Sciences, University of Waterloo, 200 University Avenue West, Waterloo, Ontario N2L 3G1, Canada
}

Received: 6 April 2004 - Revised: 19 July 2004 - Accepted: 29 July 2004 - Published: 4 August 2004

Part of Special Issue "Monitoring and modeling of landslides and debris flows"

\begin{abstract}
One hundred and one landslides were documented across $370 \mathrm{~km}^{2}$ following a rainstorm that swept the British Columbia coastline on 18 November 2001. Despite the regional nature of the storm, the landslides were spaced close together, even within the study area. Landslide clustering is attributed to high intensity storm cells too small to be recorded by the general hydrometric network. The evidence nicely corroborates previous historical studies that reached similar conclusions, but against which there was no modern analog analyzed for coastal British Columbia. Magnitudecumulative frequency data plotted well on a power law curve for landslides greater than $10000 \mathrm{~m}^{2}$, however, below that size several curves would fit. The rollover effect, a point where the data is no longer represented by the power law, therefore occurs at about 1.5 orders of magnitude higher than the smallest landslide. Additional work on Vancouver Island has provided evidence for rollovers at similar values. We propose that the rollover is a manifestation of the physical conditions of landslide occurrence and process uniformity. The data was fit to a double Pareto distribution and P-P plots were generated for several data sets to examine the fit of that model. The double Pareto model describes the bulk of the data well, however, less well at the tails. For small landslides $\left(<650 \mathrm{~m}^{2}\right)$ this may still be a product of censoring. Landscape denudation from the storm was averaged over the study area and equal to $2 \mathrm{~mm}$ of erosion. This is more than an order of magnitude larger than the annual rate of denudation reported by other authors for coastal British Columbia, but substantially less than New Zealand. The number is somewhat affected by the rather arbitrary choice of a study area boundary.
\end{abstract}

Correspondence to: R. H. Guthrie

(richard.guthrie@gems6.gov.bc.ca)

\section{Introduction}

Large storms frequently cause shallow landslides on the steep slopes of coastal British Columbia and worldwide (Caine, 1980; Church and Miles, 1987; Page et al., 1999; Zhou et al., 2002; Crosta and Frattini, 2003; Jakob and Wetherly, 2003; Guthrie and Evans, 2004; among others). These landslides are a result of increased pore pressures along a soil-bedrock interface or within the soil profile at an interface of reduced permeability. Beginning as debris slides, the translational failures often break up and propagate downslope as a flow. Entrainment and deposition zones often overlap and the erosion zone or the scar tends to be small with indistinct lower boundaries, and overlap the entrainment zone. Spatially, the landslides initiate on slopes between about $30^{\circ}$ and $45^{\circ}$ (typically mid-slope) and, in coastal British Columbia at least, tend to continue downslope to the valley floor. A general examination of the landscape suggests that debris slides and debris flows are more or less randomly distributed across these zones. More detailed analysis however, reveals that this is not in fact the case.

Recent historical analysis of landslides by Guthrie and Evans $(2003,2004)$ suggested that regional rainstorms in coastal British Columbia were felt more acutely in specific locations where convective storm cells concentrated precipitation on the landscape in excess of the typically recorded amounts. They were unable to verify their hypothesis directly as the high intensity storm cells they proposed were substantially smaller than the hydrometric network of recording stations. Instead, they cited as evidence the spatial patterns of precipitation related landslides across the landscape, noting that they were highly clustered within identified time epochs. We consider the data herein based, on a recent storm 

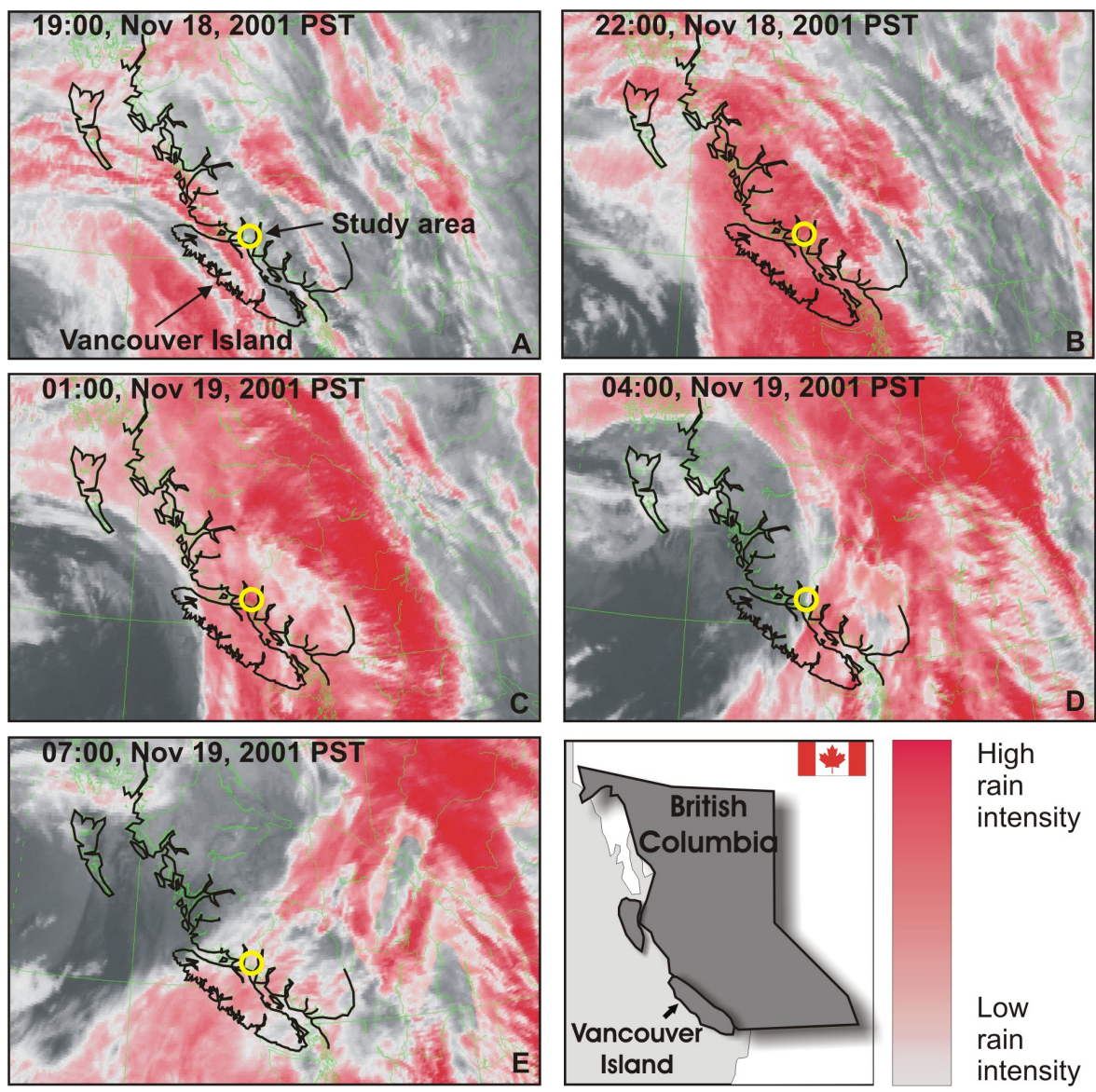

Fig. 1. The regional storm that hit coastal British Columbia on 18 November 2001, resulting in 101 landslides in the Loughborough Inlet study area (indicated by a circle on the map). GOES-10 images provided courtesy of Environment Canada.

event, strong corroborative evidence in support of that earlier contention.

Magnitude frequency curves for landslide data sets worldwide have recorded a phenomenon called rollover where the slope of the observed landslide size against probability of occurrence falls below a power law relation at smaller sizes (Hungr et al., 1999; Hovius et al., 2000; Stark and Hovius, 2001; Guzzetti et al., 2002; Martin et al., 2002; Guthrie and Evans, 2003, 2004; Brardinoni et al., 2003; Brardinoni and Church, 2004). We examine the magnitude frequency curves for landslides from a recent storm, compare them to other data from coastal British Columbia and present evidience in support of a physical expaination of the rollover effect.

A regional storm swept across coastal British Columbia on 18 November 2001 (Fig. 1). The storm was anecdotally considered a large winter storm, and was sufficiently large to trigger landslides sporadically over the Vancouver Island region. As landslide reports filtered in to the regional and district government offices, it became evident that there was an unusually high concentration of landslides across about $370 \mathrm{~km}^{2}$ of coastal mainland between Loughborough Inlet and Philips Arm (Fig. 2). Examination of the rainfall records for nearby Chatham Point revealed little. Only $36 \mathrm{~mm}$ of rainfall were recorded, less than the annual return of $43 \mathrm{~mm}$, and actually exceeded earlier that month. A preliminary examination of antecedent conditions at Chatham Point revealed that the conditions leading up to 18 November were not unusually wet. We examined the landslides in the field on 29 November 2001, and flew 1:10 000 aerial photographs over the area that included the landslide clusters a few days later. In total, 101 landslides were identified and characterized as a result of the storm.

\section{Study area}

The Loughborough Inlet study area is on the wet west coast of British Columbia, near Vancouver Island (Fig. 2). Typical annual precipitation at nearby Chatham point is approximately $2185 \mathrm{~mm}$ at sea level (Environment Canada, 1993) and expected to be greater at higher elevations. The study area itself is best described as fjordland, bound by long glacially over-steepened inlets and broad u-shaped valleys, surrounding steep rugged terrain and mountain peaks. Elevation ranges from sea level to $1769 \mathrm{~m}$ within the study area. Human activity has been extensive within the study area. In particular, there has been substantial logging and 


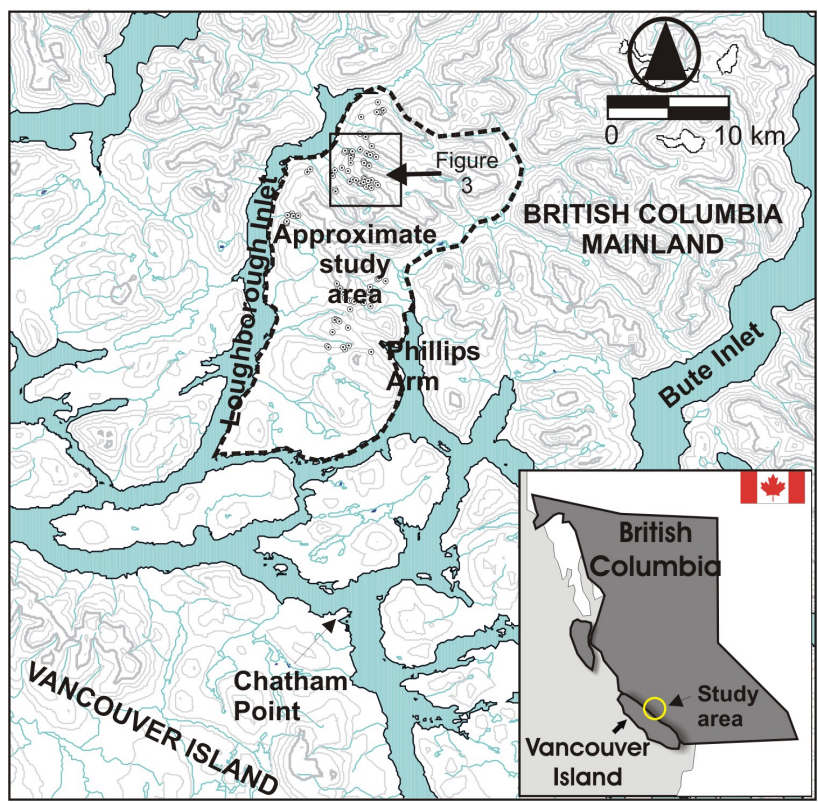

Fig. 2. Study area boundary. Inset box indicates location of Fig. 3.

road building from the turn of the Century to the present time. In a few places, logged slopes have hydrologically recovered with mature second growth nearly indistinguishable from adjacent old growth. One of the consequences of logging practices in the Loughborough Inlet study area are a tremendous number of landslides on steep slopes that predate this particular storm. This has the retrospective advantage, however, of confirming that the entire area is vulnerable to mass movements, particularly debris slides and debris flows.

Bedrock Geology is almost ubiquitously comprised of Mid-Cretaceous plutonics of undifferentiated diorite, gabbro, diabase and amphibolite. The remainder consists of a small band of Upper Triassic volcanics known as the Karmutsen Formation (Journeay et al., 2000).

Terrain generally consists of shallow colluvium over steep and moderately steep rock slopes. Exposed bedrock is prevalent at higher elevations and moraine may be present on lower slopes.

\section{Methods}

Following the regional storm on 18 November 2001, landslide reports for Vancouver Island were forwarded to the regional and district offices of the Ministry of Water Land and Air Protection. After observing the large number of clustered landslide events, we visited the Loughborough Inlet study area on 29 November, 2001. We subsequently had 1:10000 air photographs flown December 2001 of that year.

Landslides were identified as debris slides and debris flows as described by Varnes (1978) and referred to as debris avalanches by others (Swanston and Howes, 1994; Cruden and Varnes, 1996). These landslides begin as shallow translational failures, but typically break up as velocity or pore

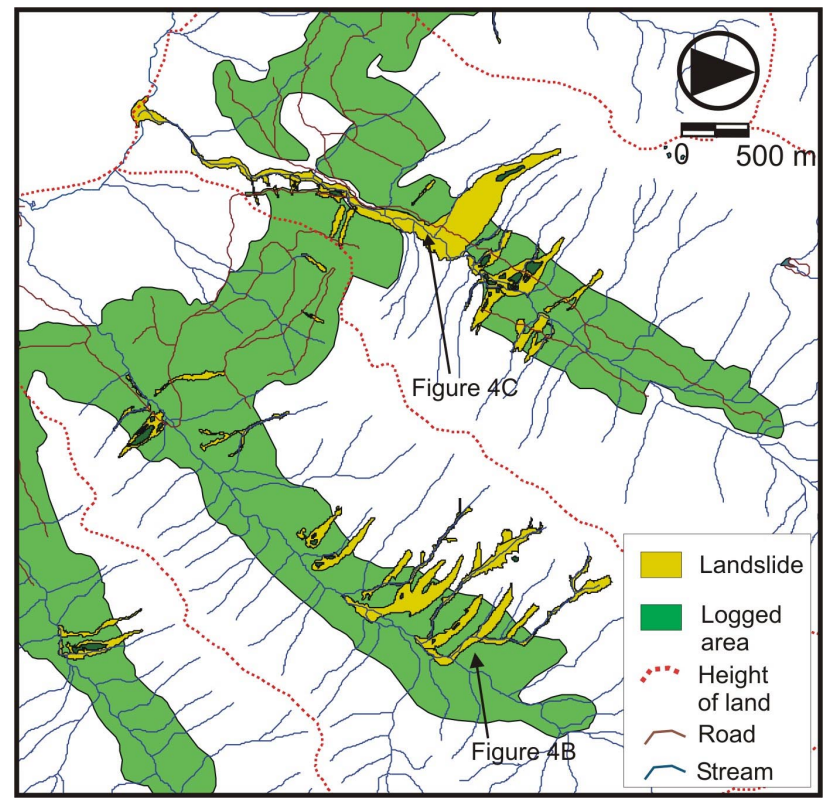

Fig. 3. Detail of landslides digitized into the GIS showing 47 of 101 landslides.

pressure increases downslope, and become an avalanche or flow.

Landslides were traced onto stereo air photographs using a digital photogrammetry system. Data was transferred into a Geographic Information System (GIS) program $\left(\right.$ ArcView $^{\mathrm{TM}}$ ) with attributes. Characteristics such as total disturbed area, connectivity to streams, other forcing factors (logging or road related for example) and so forth were generated from air photograph and GIS analysis. Figure 3 shows a detail of the study area and the associated landslides drawn in the GIS program.

The landslide distribution was plotted using cumulative probabilities on log-log scale and then compared to data from other areas on Vancouver Island plotted similarly. A probability density plot was generated using the double Pareto model of Stark and Hovius (2001) and a maximum likelihood estimation to fit the data. P-P plots comparing expected versus observed landslides were generated for Loughborough Inlet, as well as other areas on Vancouver Island to look at the voracity of the double Pareto distribution.

Landslides contours for comparison with the data from Vancouver Island were generated using Home Range Extension, an $\mathrm{ArcView}^{\mathrm{TM}}$ plug in. Home Range Extension is a point density contouring program that works in $\mathrm{ArcView}^{\mathrm{TM}}$ and uses fixed and adaptive kernel methods for generating contours.

\section{Results and discussion}

One hundred and one landslides from $1124 \mathrm{~m}^{2}$ to $409000 \mathrm{~m}^{2}$ were identified in the Loughborough Inlet study area. The field visit confirmed that landslides initiated as debris slides in the surficial deposits on steep and moderately steep hill- 

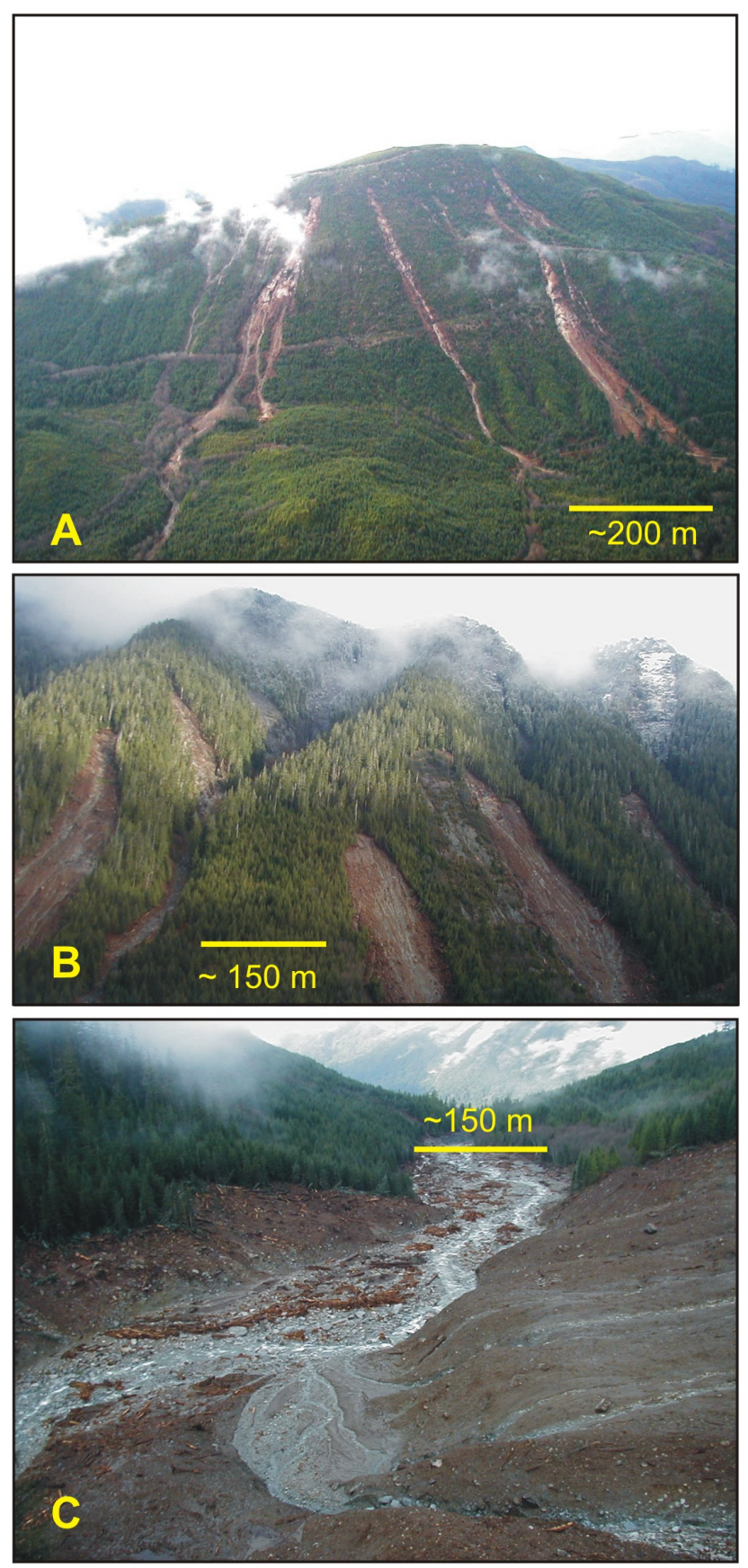

Fig. 4. Typical examples of the landslides within the study area. (A) shows landslides entirely within a cut block, (B) shows several landslides that occurred at the interface between second growth and old growth forest, and $(\mathbf{C})$ shows the damage to a stream from some of the larger landslides following the storm.

slopes. Figure 4 shows photographs of typical landslides from the study area and the impact to a stream from one of the larger failures.

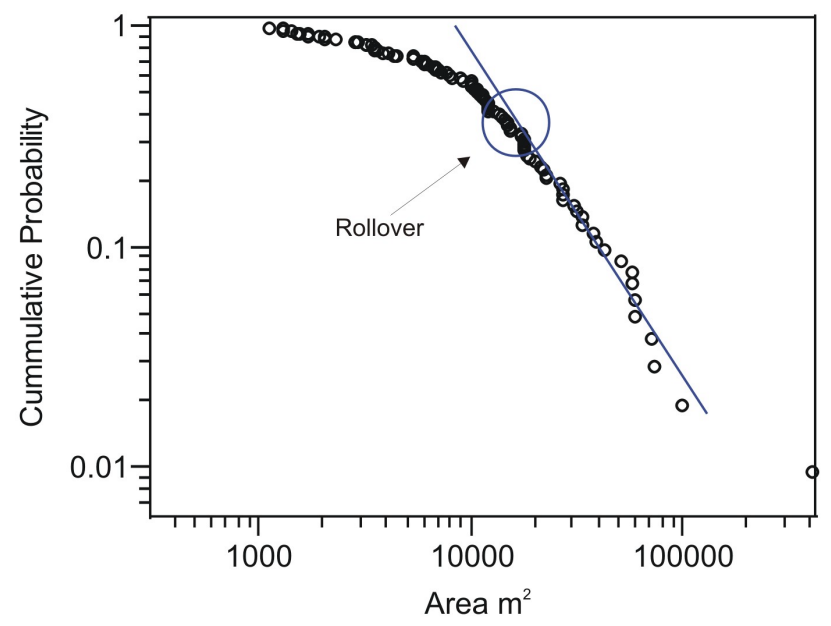

Fig. 5. The cumulative magnitude-frequency curve for the landslides from the 18 November 2001 storm in the Loughborough Inlet study area. The landslides above $10000 \mathrm{~m}^{2}$ are well described by a power law with a slope of about -1.24 . Several curves would fit the remainder of the data.

\section{Probability distributions}

The probability distribution curves of landslide magnitudes have been discussed by several authors (Hungr et al., 1999; Hovius et al., 2000; Stark and Hovius, 2001; Guzzetti et al., 2002; Martin et al., 2002; Guthrie and Evans, 2003, 2004; Brardinoni et al., 2003; Brardinoni and Church, 2004; among others). The issue is not trivial. Correct characterization of landslide frequency and magnitude is necessary for the determination of impact, landscape denudation and total risk analysis.

Typical of most landslide distributions is a power law relation for medium to large landslides (generally sizes $>1000 \mathrm{~m}^{2}$ ) with a steep negative slope that is probably related to the limitations of the landscape itself (Pelletier et al., 1997; Guzzetti et al., 2002; Brardinoni and Church, 2004; Guthrie and Evans, 2004). Historically, censoring by undersampling and other biases have been linked to the rollover effect, a point where the actual landslide distribution falls below the distribution predicted by the model (in this case a power law relation). Inability to consistently resolve small landslides has been offered as an explaination for undersampling (Hungr et al., 1999; Stark and Hovius, 2001; Brardinoni et al, 2003; Brardinoni and Church, 2004). Brardinoni et al. (2003) determined that, in the Capilano basin of coastal British Columbia, $85 \%$ of landslides were below a nominal resolution of $650 \mathrm{~m}^{2}$ and accounted for about $30 \%$ of landslide mobilised debris. However, more recent research in the same basin suggests that small landslides account for $2.7 \%$ of mobilised debris (Brardinoni and Church, 2004). This is similar to other research that indicates that the major contribution of sediment to a system comes from the moderate or large landslides (Benda and Dunne, 1997; Hovius et al., 2000; Stark and Hovius, 2001). 


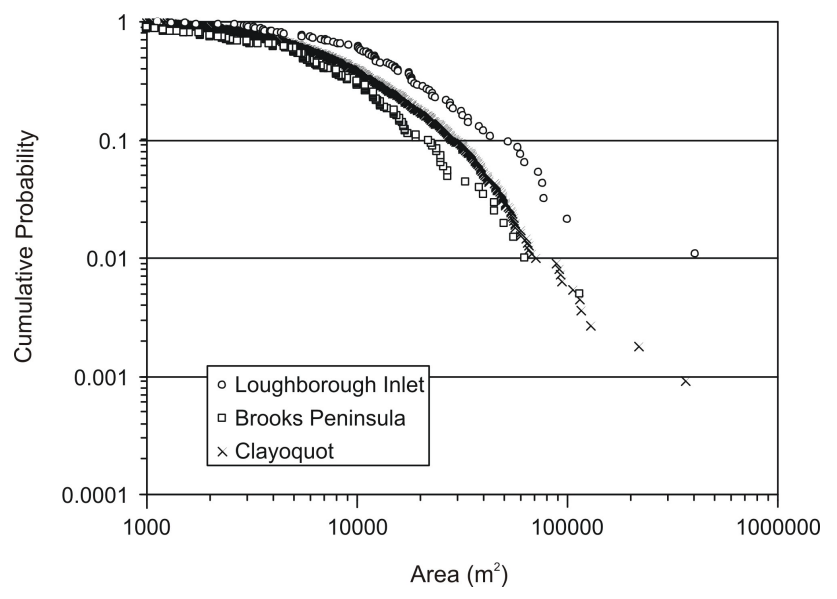

Fig. 6. A family of cumulative magnitude-frequency curves from coastal British Columbia demonstrating process uniformity. The numbers of landslides are 101, 201 and 1109 for Loughborough Inlet, Brooks Peninsula and Clayoquot respectively. The Brooks Peninsula data set does not include any landslides that are related to roads or logging, while the other two data sets include landslides related to logging practices. Despite this difference, the curves remain similar (adapted from Guthrie and Evans, 2004).

Several researchers have considered that physical reasons may also account for the rollover effect (Pelletier et al., 1997; Hovius et al., 2000; Guzzetti et al., 2002; Martin et al., 2002; Brardinoni and Church, 2004; Guthrie and Evans, 2004). To a large degree, the inability to demonstrate clearly a physical cause for rollover has been related to the small size that it has appeared in most data sets. The size (typically $<1000 \mathrm{~m}^{2}$ ) has resulted in doubt about the ability to resolve any physically attributable rollover from rollover due to data bias such as undersampling.

The cumulative frequency-magnitude distribution of 101 landslides in Loughborough inlet is given in Fig. 5. Larger landslides are generally well described by a power law relation with a slope of about -1.24 for landslides greater than about $10000 \mathrm{~m}^{2}$. Below $10000 \mathrm{~m}^{2}$ the cumulative distribution curve flattens rapidly and could be described by several relations. The rollover then occurs at approximately 1.5 orders of magnitude larger than the minimum recorded size.

The power law portion of the curve describes inherent landscape limitations. Simply put, there are substantially fewer locations within the landscape that can support landslides of incrementally greater size than $10000 \mathrm{~m}^{2}$; the larger the landslide, the more limited the opportunities. Similarly, however, the distribution of landslides smaller than $10000 \mathrm{~m}^{2}$ can also be explained by the local relief. Examining the data from Loughborough, we note that 90 of 101 landslides continued down-slope from their point of origin until they were intercepted by a major barrier. Typically (more than $50 \%$ of the time) this was a stream. Other barriers included the valley bottom or other landslides, but only 11 landslides stopped mid-slope. We argue that causative factors (in this case saturation of steep slopes with similar

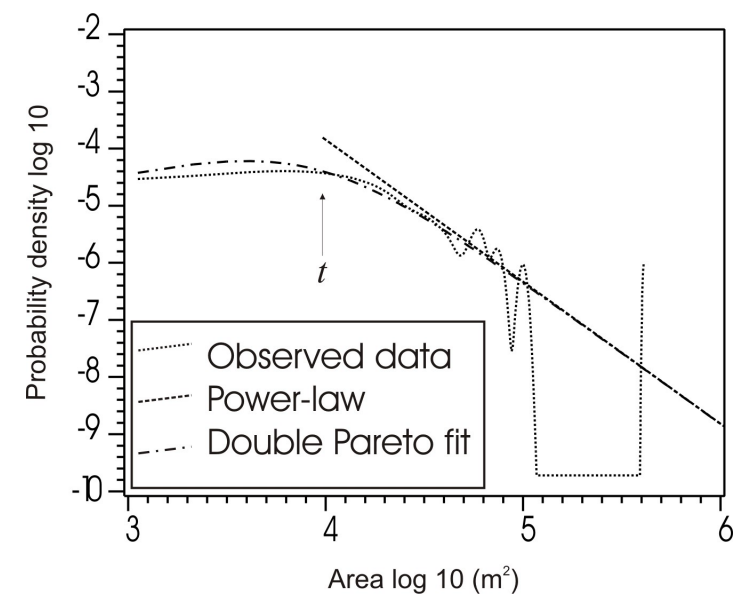

Fig. 7. Loughborough Inlet landslides plotted against the double Pareto distribution using maximum likelihood estimation. The rollover point determined by Stark and Hovius (2001), $t$, is $8882 \mathrm{~m}^{2}$, however, there is substantial variation around this number and $10000 \mathrm{~m}^{2}$ is an equally good fit (data is the same as that shown in Fig. 5).

surficial material characteristics) are ubiquitous at the time of failure, and the failure itself further loads the slope below it. Consequently, the landslides tend to a larger size until limited by a physiographic barrier, most commonly streams, gullies and valley bottoms. Consider that the landslides are most likely to initiate mid-slope; the landslide distribution curve then reflects local relief, the complexity of the landscape, and the opportunity for landslides of different size classes.

These data were compared to other data sets from Vancouver Island with remarkably similar results (Fig. 6). Data describing debris slides and debris flows greater than $500 \mathrm{~m}^{2}$ from Brooks Peninsula and Clayoquot Sound on the west coast of Vancouver Island also demonstrate the rollover effect at sizes larger than $10000 \mathrm{~m}^{2}$. These similarities prevail despite substantial differences in the characteristics of landslides that are tentatively related to forcing mechanisms, as well as differences in timing (and therefore the completeness of the sets): approximately $60 \%$ of the landslides from the single storm in Loughborough Inlet are related to logging (open slope clear-cut failures or road related failures). In contrast, 201 landslides in Brooks Peninsula were natural and comprised a complete set spanning more than 60 years (Guthrie and Evans, 2004). In Clayoquot, another comprehensive set of 1009 landslides and spanning decades is a mix of natural and logging related events.

Brardinoni and Church (2004) have recently determined for another coastal British Columbia watershed, that a change occurs in the magnitude frequency curve for landslides greater than about $4000 \mathrm{~m}^{3}$. In terms of the total disturbed area, this would indicate a change when size exceeds $10000 \mathrm{~m}^{2}$. Brardinoni and Church also suggest that physical explanations may account for this change. 


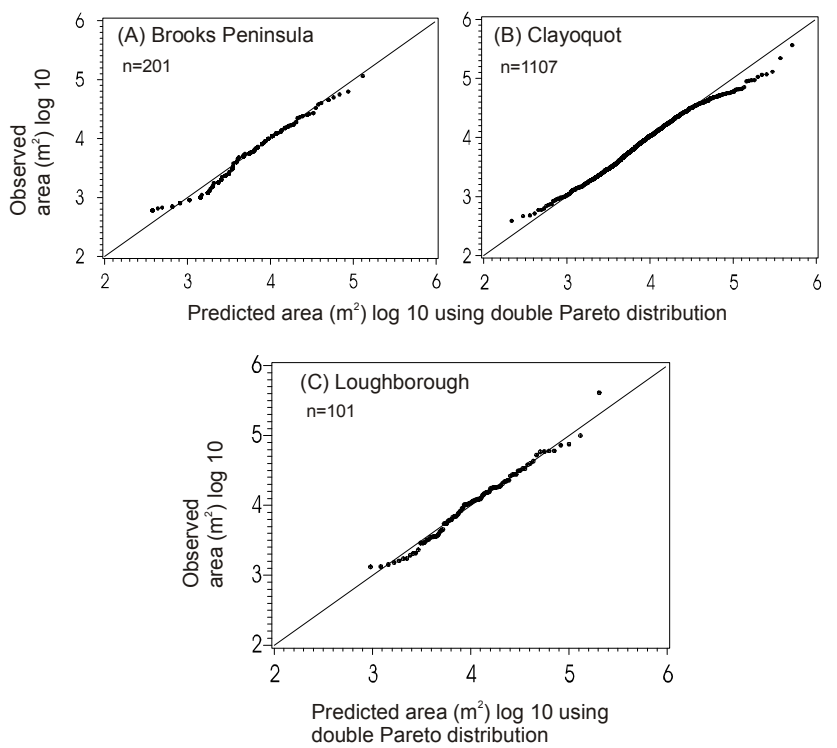

Fig. 8. Quantile probability plots of the double Pareto distribution for all three data sets. These plots indicate that while the double Pareto distribution predicts the bulk of the data well, it does so less well at the tails. Below $650 \mathrm{~m}^{2}$ there may still be a censoring effect.

Whether by sampling artefact or by physical design, Stark and Hovius (2001) argued that the landslide distribution was better predicted using the double Pareto model. We used maximum likelihood estimation to plot the landslides on the double Pareto curve (Fig. 7). The bulk of the data plots well, Stark and Hovius (2001) determined a rollover function $t$ which is equivalent to $8882 \mathrm{~m}^{2}$ in Loughborough. However, Guthrie and Evans (2004) pointed out that Wald confidence limits show tremendous variability in the value of $t$ and we argue that $10000 \mathrm{~m}^{2}$ is equally acceptable.

We looked in detail at the ability of the double Pareto model to accurately predict the range of landslides occurring by examining quantile probability plots on the data from Loughborough Inlet, as well as for Brooks Peninsula and Clayoquot. The results in Fig. 8 indicate that the double Pareto model predicts the majority of the landslide data well, however, less well at both tails. For landslides less than about $630 \mathrm{~m}^{2}(\operatorname{area} \log 10=2.8)$ in the historical data sets, and less than about $1000 \mathrm{~m}^{2}$ in Loughborough there appears to be fewer small landslides than predicted by the double Pareto curve. Once again we are faced with the possibility of sampling error at these sizes. We note that $630 \mathrm{~m}^{2}$ is similar to the value given by Brardinoni et al. (2003) of $650 \mathrm{~m}^{2}$ for minimum consistently resolvable size in coastal British Columbia watersheds from air photograph. We also note, however, in the Loughborough case, that the air photographs were 1:10000 and suggest that it may be only a case of the landslide sample size. More disconcerting is the fact that, for landslides larger than about $60000 \mathrm{~m}^{3}$, the double Pareto curve appears to predict more than the number of observed events. It is possible that this is a data biasing error in the other direction; that is to say that large landslides occur too infrequently to observe. We argue, however, that while that might be true for Loughborough as a temporally limited data set, that the same cannot be said for Brooks Peninsula or Clayoquot. Even infrequent large landslides of otherwise similar characteristics are likely to be spotted over 50 years of air photographs as they tend to persist in the landscape substantially longer than landslides of smaller dimensions. Once again, we are drawn to the similarity between all data sets and posit a physical explanation for the distributions.

\subsection{Spatial distribution and implications}

Studies in landslide dynamics often focus on causal mechanisms, relating landslide initiation and frequency to storms and storm size (Caine, 1980; Schwab, 1983; Church and Miles, 1987; Page et al., 1994; Guthrie, 1997; Zhou et al., 2002; Jakob and Weatherly, 2003; Guthrie and Evans, 2004; among others). Caine (1980) first addressed precipitation thresholds to landslides suggesting minimum rainfall intensities of $100 \mathrm{~mm} \cdot 24^{-1} \mathrm{~h}$. The application of these intensities to coastal British Columbia has been difficult, however, and landslides have been documented at lower rainfall intensity, and storms exceeding this intensity have occurred without consequent landslides (Church and Miles, 1987; Guthrie, 1997, Jakob and Weatherly, 2003). This study is a case in point. If we look at the records from the nearest hydrometric station, Chatham Point (Fig. 2), they would suggest that while a storm came through, it did not even exceed the annual maximum. Church and Miles (1987) and Jakob and Weatherly (2003) have argued that intensities alone are not indicative of landslide potential, but must be considered with antecedent moisture conditions. Once again, however, at this site a preliminary look at the antecedent conditions suggests that the area was not particularly "wet".

Compounding the difficulties of applying rainfall intensities thresholds to coastal British Columbia is the fact that British Columbia's hydrometric network is inadequate to realistically represent the spatial variation in precipitation patterns. In addition, most stations are at sea level so that the orographic effect ubiquitous across the landscape is poorly modelled. We argue that for this storm, the nearest precipitation records are essentially useless in terms of prediction of the landslides recorded in the Loughborough Inlet area.

Antecedent conditions not withstanding, we argue that intensity remains a critical factor and that the conditions for landslide initiation tend to be complicated by local intense storm convective storm cells within regional events that are unlikely to be recorded by the nearest hydrometric station. Guthrie and Evans (2004) argued that this was the case with historical landslides on Brooks Peninsula on Vancouver Island. To whit, Fig. 9 shows the landslides that occurred between 1980 and 1995 in the Brooks Peninsula study area. Landslides are strongly clustered to two areas, and heights of land appear to define at least some of the boundaries affected by the landslide clusters. We consider the landslide within Loughborough Inlet to be strong corroborating evidence for the existence of high intensity storm cells within 


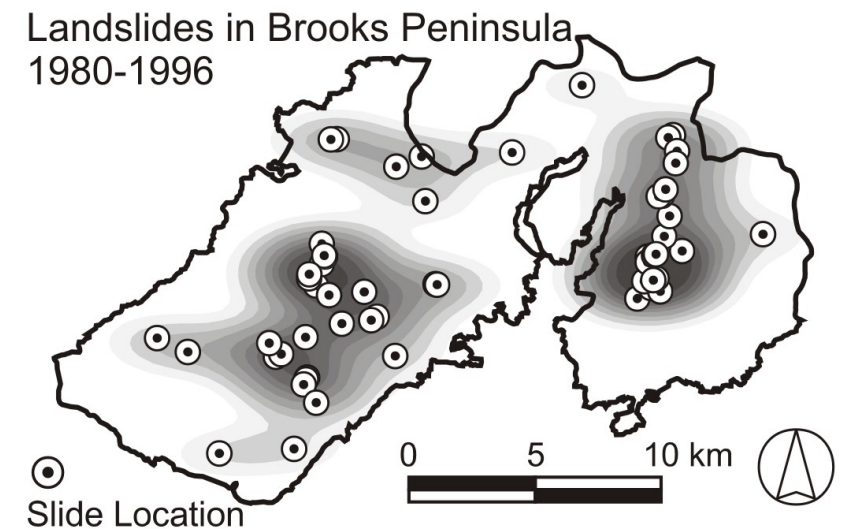

Fig. 9. Fifty five landslides contoured (using fixed kernel methods) for Brooks Peninsula between 1980 and 1996. The clustering of data strongly resembles tracks and Guthrie and Evans (2004) proposed high intensity storm cells as the cause (adapted from Guthrie and Evans, 2004).

regional storm events. Figure 10 shows the contoured distribution of landslides within the study area following the 2001 storm. We note the landslides are tightly clustered, similar to the historical Brooks Peninsula data set. Adjacent and nearby watersheds, physiographically similar and with evidence of past instability, showed little or no sign of disturbance. We expect that antecedent conditions are probably not sufficiently different within the study area to account for the clustering, and argue that it was a coupling of those conditions with high intensity storm cells that caused the landslides to occur. This would agree with Jakob and Wetherly's (2002) general model of landslide initiation.

Logging is also often related to landslide initiation on the coast in much the way that antecedent moisture conditions are considered. That is to say that logging activities set the stage to increase the vulnerability of the landscape (Howes and Sondheim, 1988; Rollerson, 1992; Rollerson et al., 1998; Jakob, 2000; Guthrie, 2002; among others). In Loughborough Inlet approximately $60 \%$ of the landslides were either road or logging related (25 and 36 of 101 events, respectively). Further analysis of the density statistics, such as the relative contribution of each, however, is complicated by the clustering of the events themselves. Because of the narrow distribution of landslides, events per unit area, stratified by those either logging related or not, become highly dependent on the rather arbitrary selection of study area boundaries. We offer instead only these qualitative observations related to forest cover. Many landslides not related to logging activities were nevertheless associated with thinning or absent forests related to snow avalanching. Several natural landslides expanded substantially in size around the logged boundary and had a much higher consequent impact on the landscape. The latter observation is important in terms of impacts, but it is rarely addressed in the literature.

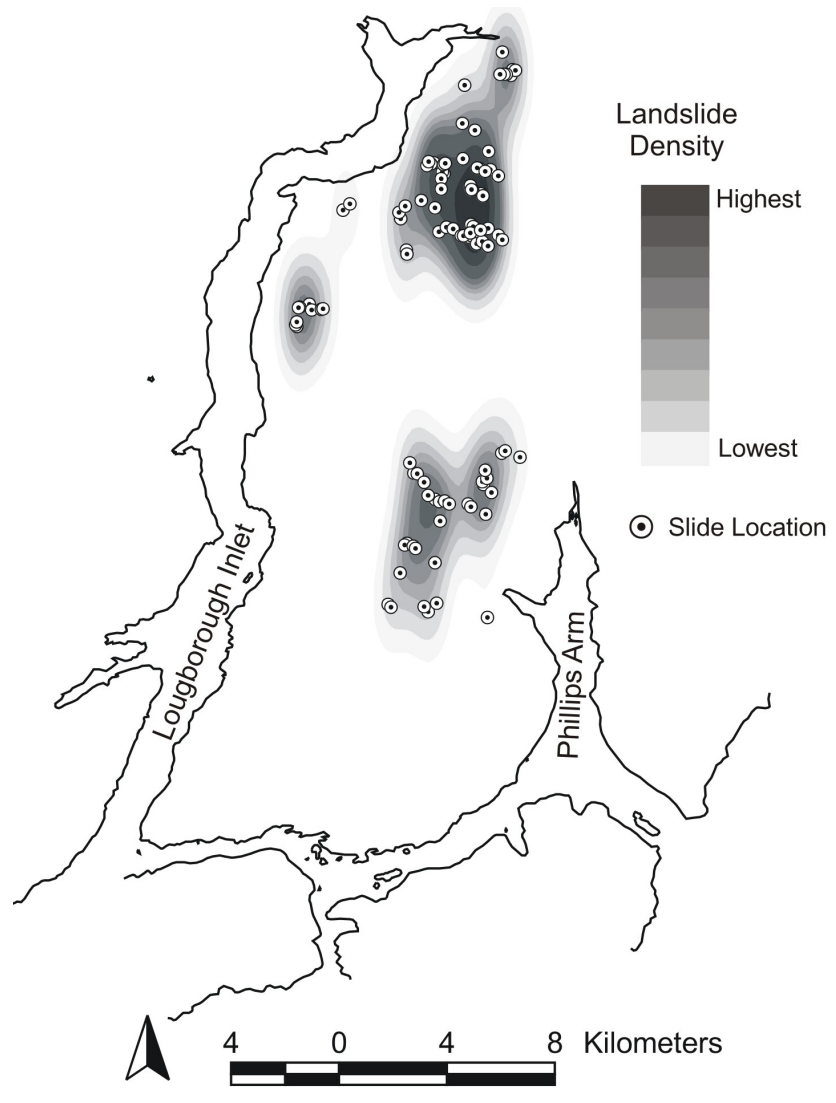

Fig. 10. Landslide clustering following the November 2001 storm in the Loughborough Inlet study area using the same method of contouring as in Fig. 9. Note the similarity between the contours in Fig. 9.

\subsection{Landscape denudation}

The total area eroded by landslides related to the 18 November storm was about $2070000 \mathrm{~m}^{2}$. The average landslide size was $20498 \mathrm{~m}^{2}$ and recorded landslides ranged from $1124 \mathrm{~m}^{2}$ to $409000 \mathrm{~m}^{2}$. About half the landslides hit a stream and the largest landslide buried about $3 \mathrm{~km}$ of stream length.

Remote estimation of volumes for shallow debris slides and debris flows in Coastal British Columbia is problematic for several reasons including frequent removal of depositional material by a stream, indistinct initiation zone boundaries and entrainment of debris along the landslide track. Martin et al. (2002), attempted to estimate landslide volumes from air photographs using a weighted formula to address the initiation and entrainment zones separately, however, their results were variable. Guthrie and Evans (2004) applied detailed surveys of 124 landslides in the Queen Charlotte Islands where physiological conditions are similar to derive an empirical formula based on the total disturbed area of a shallow debris slide or flow. The advantage to this method is primarily that total disturbed area may be accurately characterized on air photographs. 
$V=0.1549 A^{1.0905}$ where $V=$ landslide volume in $\mathrm{m}^{3}$ and $A=$ total area in $\mathrm{m}^{2}$. The formula does not assume constant depth down a landslide track, but that a landslide track is likely to contain areas of erosion, entrainment and deposition.

Applied to 101 landslides in Loughborough Inlet, the formula yields approximately $720000 \mathrm{~m}^{3}$ of sediment eroded by landslides, with individual values ranging from about $280 \mathrm{~m}^{3}$ to $172000 \mathrm{~m}^{3}$. The mean landslide contribution was approximately $7100 \mathrm{~m}^{3}$; however, this was skewed considerably by a single large $\left(409000 \mathrm{~m}^{2}\right)$ event that yielded $172000 \mathrm{~m}^{3}$ of sediment. Not including that event, the mean landslide volume was still large at about $5500 \mathrm{~m}^{3}$.

The storm contributed substantially to overall landscape denudation. While not representative of the actual spatial distribution of the landslides, the equivalent of $1945 \mathrm{~m}^{3} \cdot \mathrm{km}^{-2}$ was eroded from the landscape, or an average downwasting of approximately $2 \mathrm{~mm}$ in the study area. This is substantially more than the annual rates reported by Guthrie and Evans (2004) and Martin et al. (2002) for Brooks Peninsula and the Queen Charlotte Islands respectively by at least an order of magnitude $\left(0.06 \mathrm{~mm} \cdot \mathrm{y}^{-1}\right.$ and $0.1 \mathrm{~mm} \cdot \mathrm{y}^{-1}$, respectively).

Despite the high denudation value relative to other coastal British Columbia examples, this event is not remarkable world-wide. In another comparison, landscape denudation that resulted from the November 2001 storm in the Loughborough Inlet area is about 10 times less than reported by Page et al. (1994) following a New Zealand cyclone in 1988. Page et al. (1999) reported considerable spatial variability of landslides, related in part to the inherent vulnerability of landslide prone physiographic units. Based on their photographs and data, however, the general picture that a New Zealand cyclone caused landslides an order of magnitude greater than experienced in the Loughborough Inlet study area is reasonable. This probably relates to bedrock and surficial geology as well as New Zealand's tectonic regime which includes uplift rates of about $7 \mathrm{mmm} \cdot \mathrm{y}^{-1}$ (Hovius et al., 1997).

Locally, the large contribution to denudation from the November 2001 rainstorm suggests several things. First, it confirms the periodicity of landslide forcing factors (earthquakes, high intensity storm cells) such that the absence of additional similar storms over time would lower the denudation rate. Second, it alludes to the difficulties related to study scale (the concentration or dilution of the landslide effect depending on the size of the study area). Third, it implies that landscapes need not be equally vulnerable to erosion whatever the forcing mechanism. Lastly, with $60 \%$ of the landslides being logging related, there is also continued evidence for the anthropogenic contribution to landscape erosion.

\section{Conclusions}

One hundred and one landslides ranging in size from $1124 \mathrm{~m}^{2}$ to $409000 \mathrm{~m}^{2}$ were recorded and analyzed in Loughborough Inlet following a rainstorm that swept across coastal British Columbia on 18 November 2001. Based on the analysis of this data and comparative analysis of historic data for coastal British Columbia, we draw the following conclusions.

1. The rollover effect in magnitude-frequency distributions are not merely an artefact of censoring, but represent a physical manifestation of the conditions under which the landslides occur. In the case of coastal $\mathrm{BC}$ watersheds, the rollover seems to occur at or near $10000 \mathrm{~m}^{2}$, nearly 1.5 orders of magnitude larger than our minimum recorded landslide size. We note that for total disturbed areas below about $630 \mathrm{~m}^{2}$ there may remain a censoring effect. We also note that for larger landslides $\left(>60000 \mathrm{~m}^{2}\right)$, the double Pareto curve may in fact over predict landslide probability.

2. The spatial distribution of landslides suggests that there are high intensity storm cells within regional precipitation events. These cells are generally expected to be too small to be picked up on the hydrometric network except by remarkable chance. This makes it difficult to estimate accurately the return periods of rainstorm intensities that cause numerous failures. It nevertheless has bearing on the general nature of landslide prediction, particularly related to climate change where, for coastal British Columbia, the general scenarios predict increased storm frequencies and intensities. These findings corroborate evidence for the same behaviour from historical records on Vancouver Island.

3. Landscape denudation based on the single storm, averaged over about $370 \mathrm{~km}^{2}$ of land delineated as the study area was $2 \mathrm{~mm}$. This was more than an order of magnitude higher than other reported annual denudation rates for coastal BC, but an order of magnitude less than those reported for a major cyclone in New Zealand.

Acknowledgements. M. Jaboyedoff and one anonymous reviewer critically read the manuscript and provided valuable suggestions. C. Schwarz assisted with the statistical analysis of data and R. Pettit and S. Lindsay provided digitizing and GIS-related assistance.

Edited by: J. B. Crosta

Reviewed by: M. Jaboyedoff and another referee 


\section{References}

Benda, L. and Dunne, T.: Stochastic forcing of sediment supply to the channel networks, Water Resources Research, 33, 28652880, 1997.

Brardinoni, F. and Church, M.: Representing the landslide magnitude-frequency relation: Capilano River Basin, British Columbia, Earth Surface Processes and Landforms, 29, 115-124, 2004.

Brardinoni, F., Slaymaker, O., and Hassan, M.A.: Landslides inventory in a rugged forested watershed: a comparison between air-photo and field survey data, Geomorphology, 54, 179-196, 2003

Caine, N.: The rainfall intensity-duration control of shallow landslides and debris flows, Geografiska Annaler Series, A62, 23-27, 1980.

Church, M. and Miles, M. J.: Meterological antecedents to debris flow in southwestern British Columbia; some case studies, In: Debris Flows/Avalanches: Process, Recognition, and Mitigation, edited by Costa, J. E., and Wieczorck, G. F., Geological Society of America, Reviews in Engineering, 7, 17-22, 1987.

Crosta, G. B. and Frattini, P.: Distributed modelling of shallow landslides triggered by intense rainfall, Natural Hazards and Earth System Sciences, 3, 81-93, 2003.

Cruden, D. M. and Varnes, D. J.: Landslide types and processes. In: Landslides, Investigation and Mitigation, edited by Turner, A. K. and Schuster, R. L., Transportation Research Board, National Research Council, Special Report 247, Washington DC, 36-75, 1996.

Environment Canada: Canadian Climate Normals, 1960-1990, Environment Canada, Ottawa, ON, 1993.

Guthrie, R. H.: The effects of logging on frequency and distribution of landslides in three watersheds on Vancouver Island, British Columbia, Geomorphology, 43, 273-292, 2002.

Guthrie, R. H.: The characterization and dating of landslides in the Tsitika River and Schmidt Creek watersheds, Northern Vancouver Island, British Columbia, M. Sc. Thesis, University of Victoria, Victoria, BC, 1997.

Guthrie, R. H. and Evans, S. G.: Landslides in the Brooks Peninsula study area, Vancouver Island; landscape evolution in a natural system, Geophysical Research Abstracts, European Geophysical Society, 5, 07759, 2003.

Guthrie, R. H. and Evans, S. G.: Analysis of landslide frequencies and characteristics in a natural system, coastal British Columbia, Earth Surface Processes and Landforms, in press, 2004.

Guzzetti, F., Malamud, B. D., Turcotte, D. L., and Reichenbach, P.: Power-law correlations of landslide areas in central Italy, Earth and Planetary Science Letters, 195, 169-183, 2002.

Hovius, N., Stark, C. P., and Allen, P. A.: Sediment flux from a mountain belt derived by landslide mapping, Geology, 25, 231234, 1997.

Hovius, N., Stark, C. P., Hao-Tsu, C., and Jiun-Chuan, L.: Supply and removal of sediment in a landslide-dominated mountain belt: Central Range, Taiwan, Journal of Geology, 108, 73-89, 2000.

Howes, D. E. and Sondheim, M.: Quantitative definitions of stability classes as related to post-logging clearcut landslide occurrence. In: Proceedings of the 10th B. C. Soil Science Workshop, British Columbia Ministry of Forests Land Management Report, $56,167-184,1988$.
Hungr, O., Evans, S. G., and Hazzard, J.: Magnitude and frequency of rock falls and rock slides along the main transportation corridors of southwestern British Columbia, Canadian Geotechnical Journal, 36, 224-238, 1999.

Jakob, M.: The impacts of logging on landslide activity at Clayoquot Sound, British Columbia, Catena, 38, 279-300, 2000.

Jakob, M. and Wetherly, H.: A hydroclimatic threshold for initiation on the North Shore Mountains of Vancouver, British Columbia, Geomorphology, 54, 137-156, 2003.

Journeay, J. M., Williams, S. P., and Wheeler, J. O.: Tectonic assemblage map, Vancouver, British Columbia-USA. Geological Survey of Canada, Open File 2948a, scale 1:1 000 000, Ottawa, ON, 2000.

Martin, Y., Rood, K., Schwab, J. W., and Church, M.: Sediment transfer by shallow landsliding in the Queen Charlotte Islands, British Columbia, Canadian Journal of Earth Science, 39, 1890 205, 2002.

Page, M. J., Trustrum, N. A., and Dymond, J. R.: Sediment budget to assess the geomorphic effect of a cyclonic storm, New Zealand, Geomorphology, 9, 169-188, 1994.

Page, M. J., Reid, L. M., and Lynn, I. H.: Sediment production from Cyclone Bola landslides, Waipaoa catchment, Journal of Hydrology (NZ), 38, 289-308, 1999.

Pelletier, J. D., Malamud, B. D., Blodgett, T. A., and Turcotte, D. L.: Scale-invariance of soil moisture variability and its implications for the frequency-size distribution of landslides, Engineering $\mathrm{Ge}$ ology, 48, 254-268, 1997.

Rollerson, T. P.: Relationships between landscape attributes and landslide frequencies after logging: Skidegate Plateau, Queen Charlotte Islands. British Columbia Ministry of Forests Land Management Report, 76, Victoria, BC, 1992.

Rollerson, T. P., Jones, C., Trainor, K., and Thomson, B.: Linking post-logging landslides to terrain variables: Coast Mountains, British Columbia-preliminary analyses. In: Proceedings of the 8th International Congress of the International Association for Engineering Geology and the Environment, Balkema Rotterdam, 3, 1973-1979, 1998.

Schwab, J. W.: Mass wasting: October - November 1978 storm, Rennell Sound, Queen Charlotte Islands, British Columbia Ministry of Forests, Research Note 91, Victoria, BC, 1983.

Stark, C. P. and Hovius, N.: The characterization of landslide size distributions, Geophysical Research Letters, 28, 1091-1094, 2001.

Swanston, D. N. and Howes, D. E.: Slope movement processes and characteristics. In: A Guide for Management of Landslide Prone Terrain in the Pacific Northwest, edited by Chatwin, $\mathrm{S}$. C., Howes, D. E., Schwab, J. W., and Swanston, D. N., British Columbia Ministry of Forests, Land Management Handbook 18, Victoria BC, 1-17, 1994.

Varnes, D. J.: Slope movement types and processes. In: Landslides; Analysis and Control, edited by Schuster, R. L. and Krizck R. J., Transportation Research Board national Academy of Sciences Special Report 176, Washington DC, 11-33, 1978.

Zhou, C. H., Lee, C. F., Li, J., and Xu, Z. W.: On the spatial relationship between landslides and causative factors on Lantau Island, Hong Kong, Geomorphology, 43, 197-207, 2002. 